\title{
The philosopher in the kitchen: the rôle of mathematical modelling in explaining drumlin formation
}

\author{
A. C. Fowler ${ }^{1,2}$ \\ ${ }^{1}$ MACSI, University of Limerick, Limerick, Ireland \\ ${ }^{2}$ OCIAM, University of Oxford, Oxford, UK
}

February 19, 2018

\begin{abstract}
Scientific progress does not take place in a linear fashion, but often occurs through sudden advances following years of stagnation, in the course of which quite heated battles between proponents of different viewpoints can occur. In this paper, we review several instances of such debates, and use them to throw light on a current philosophical tussle between proponents of different explanations for the formation of drumlins, and other subglacial bedforms. We conclude that the differences of opinion which emerge in the literature may be more an issue of semantics rather than a fundamental disagreement about process. In addition, we provide a critical review of some recent theories of drumlin formation, highlighting their merits and demerits, as well as defending them against some of the criticism they have received.
\end{abstract}

Keywords: drumlin theory, equifinality, equicausality, instability theory.

Dedicated to Per Möller on the occasion of his retirement.

\section{Introduction}

Pfuel was one of those theorists who so love their theory that they forget the purpose of the theory - its application in practice; in his love for theory, he hated everything practical and did not want to know about it. He was even glad of failure, because failure, proceeding from departures from theory in practice, only proved to him the correctness of his theory.

Tolstoy, War and Peace, III, I, X. 
Genuine applied mathematicians live at the boundaries of their subject. In the territories outside live physicists, chemists, biologists, geologists, volcanologists, geographers, ...: there are many different territories; the landscape looks different in each. The applied mathematician lives at the fences between the fields. He sees what happens outside, but he uses his own tools to try and understand what he sees. 'No man is an Iland', in John Donne's famous phrase', and the same should be true of scientific subjects, but the territorial nature of science breeds in some a similar territoriality. This varies somewhat: in my opinion, geophysicists tend to be inwardlooking, while glaciology has historically been one of the most outward-looking and all-embracing of subjects; although not always.

Applied mathematicians are in an awkward position here. Because for the most part they are not in the data-gathering business themselves, there is a tendency for them to be looked down on, as only theoreticians. This attitude is accentuated because of the unfortunate fact that almost every paper will have some sort of model built into its conclusions, even if this simply takes the form of putting a straight line through a cloud of points, and interpreting the result as indicating a causative relationship. The first part of the title of the present paper is that of a translation of a book by Jean-Anthelme Brillat-Savarin, published in 1825 with the original title $L a$ physiologie du goût, and translated by Anne Drayton for Penguin Books in 1970. The book was not a cookbook, but a philosophical discourse on food and drink. The title of the translation carries several meanings; most obviously, it is indeed the musings of a philosopher in the realm of the kitchen. But Brillat-Savarin was no professional cook, he was actually a lawyer, and thus someone taking ownership of a subject which others might think inappropriate. And I think the theoretician in an experimental subject is precisely in the position implied by both of these meanings.

Tolstoy's quotation above, though applied to a military general, serves as a dire warning to people like myself who claim to apply their theories to reality, because, unfortunately but inevitably, mathematicians like to do mathematics, and the lure of the subject tends to lead them away from what should be their most important goal, that of explaining reality as it is observed.

One ongoing scientific controversy occurs in the literature on drumlins and other subglacial bedforms, and we will focus on this. To paraphrase its extremes, there are two end members: on the theoretical side, people such as myself seek to explain the formation of many bedforms, including drumlins, ribbed moraine and mega-scale glacial lineations (MSGL), as arising from different parameter régimes of a single unifying model (Clark 2010). Some authors limit themselves to ribbed moraine, for example Dunlop et al. (2008); others seek uniformity across the three types described above (e.g., Fowler and Chapwanya 2014), although other bedforms such as whalebacks and glacial flutes go unmentioned. The other end member (in my interpretation) states that only field observations can delineate the process of formation, and

\footnotetext{
${ }^{1}$ The phrase occurs in his prose work Devotions upon emergent occasions, published in 1624, written in 23 sections, each comprising a meditation, expostulation and prayer, written during the course of an unknown disease which afflicted him for 23 days; the famous passage, ending with the exhortation 'And therefore never send to know for whom the bell tolls; It tolls for thee', is in meditation 17.
} 
such observations tell us that there are indeed many different such processes (Möller 2006, 2010); these differing processes provide the underlying topography, and the consequence of ice flow over the bedforms is such as to produce a relatively uniform result: this is the idea of equifinality. These different viewpoints are held quite forcefully by different groups, and such differences can lead to a mutual antagonism. But I will argue that the perceived difference may be, to some extent, a semantic one.

\section{The process of modelling}

Hooke (2003) provides an interesting perspective on modelling from the point of view of a scientist; he describes four different kinds of models: conceptual, physical, analytical and numerical, and gives examples of each. The conceptual model is an idea. I would call Shaw's flood model, discussed later, a conceptual model. By a physical model, Hooke refers to experimental models, as for example those of Huppert and Sparks representing processes in magma chambers (e.g., Huppert 2000). An applied mathematician would take a parallel view. To him, these four components together constitute a model. There is the concept, and then secondarily, the physical process which it embodies. There may be experiment, but this is not always possible. The same applies to field work. But a model carries through from the concept and the process to some kind of analytical and/or numerical study. From my perspective, a model without this latter content remains a speculative idea. Others will have different viewpoints.

By a modeller, I therefore mean a person such as myself who builds descriptions of physical processes with a view to explaining observed phenomena. Actually, what I do is not quite what many people think of as modelling. Scientists talk of 'numerical modellers', with a covert implication that the bulk of the effort is devoted to the computational effort involved in solving the model, with a lesser effort on building the constitutive ingredients of the model; the two components are related but are not identical; and, I would argue, it is the construction of the model which is the more important scientific step, even though it may be less visible: the activity of model-building is an intricate and non-trivial one.

Let us take an example, that of the formation of hillslope topography, such as in figure 1. It is well understood by geomorphologists (or at least is well accepted) that the corrugated topography seen in figure 1 is due to the erosive action of water, and a possible model describing this is that due to Smith and Bretherton (1972). This model describes the overland flow of water (given by the St. Venant equations), coupled to an Exner equation describing the conservation of hillslope sediment under conditions in which sediment is transported downslope by, for example, bedload transport. Other erosive processes which occur during unponded surface flow include rainsplash erosion and soil creep. There are various conceptual difficulties with the model as stated (see for example Fowler et al. (2007)), but these are of minor concern. The SmithBretherton model assumes a constant rainfall which feeds a flowing water film. In a uniform state, this film takes the form of a millimetres-thick film, which is unstable to the formation of rills, due to the fact that a local thickening of the film will cause increased basal stress, which in turn causes increased sediment erosion, thus 


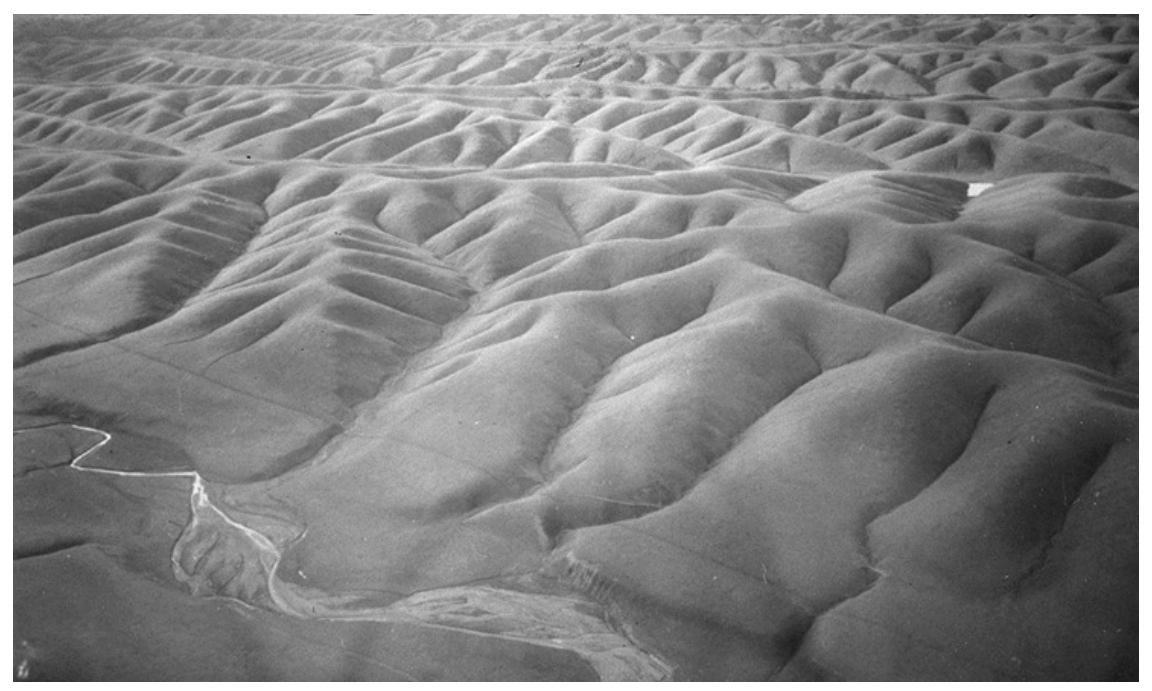

Figure 1: An example of hillslope topography on the east side of the Pacific Coast range, southwest of Orland, California. Photograph courtesy of Gary Parker.

deepening the incipient channel further; this positive feedback is the cause of the rilling instability, and it is thought that this is the precursor to the formation of mature hillslope topography over periods of millions of years. Unfortunately, the wide variation in time and space scales inherent in the problem have prevented direct numerical solution of the Smith-Bretherton model, and theoreticians have resorted to the use of lattice-type models ${ }^{2}$ (Kramer and Mardar 1992, Tucker and Slingerland 1994); by their nature, these are one step further removed from the physical processes involved.

There are various objections one might make to this theory. For a start, a millimetre-thick water film is unlikely to be able to erode any soil at all, particularly if the ground is vegetated. Second, steep bedrock mountain streams can hardly provide a sediment flux, as there is no sediment! Thirdly, in high mountain areas, erosion sometimes does not occur through water flow at all, but by landslides; or, where there are glaciers, through the grinding and crushing of bedrock by the ice. So we might say that there are numerous processes which can cause nested sets of valleys, but that there is equifinality in the sense that all of these erosional processes apparently lead to similar networks of valleys with primary, secondary and tertiary arms, as indicated in figure 1.

What would a modeller think of this? The answer is that the modeller sees all these processes as essentially the same mechanism. The Smith-Bretherton model describes a combination of water flow and sediment erosion and transport; the important components of the model are the fact there is a sediment flux downslope and a flow transport mechanism. Landslides occur because of the steepness (and relief) of

\footnotetext{
${ }^{2}$ A lattice model refers to a physical description of a process where the variables are assigned values at discrete lattice points, and these are evolved in time by specified rules describing interaction with neighbouring lattice points. Usually the rules are inspired by physical process, though not always.
} 


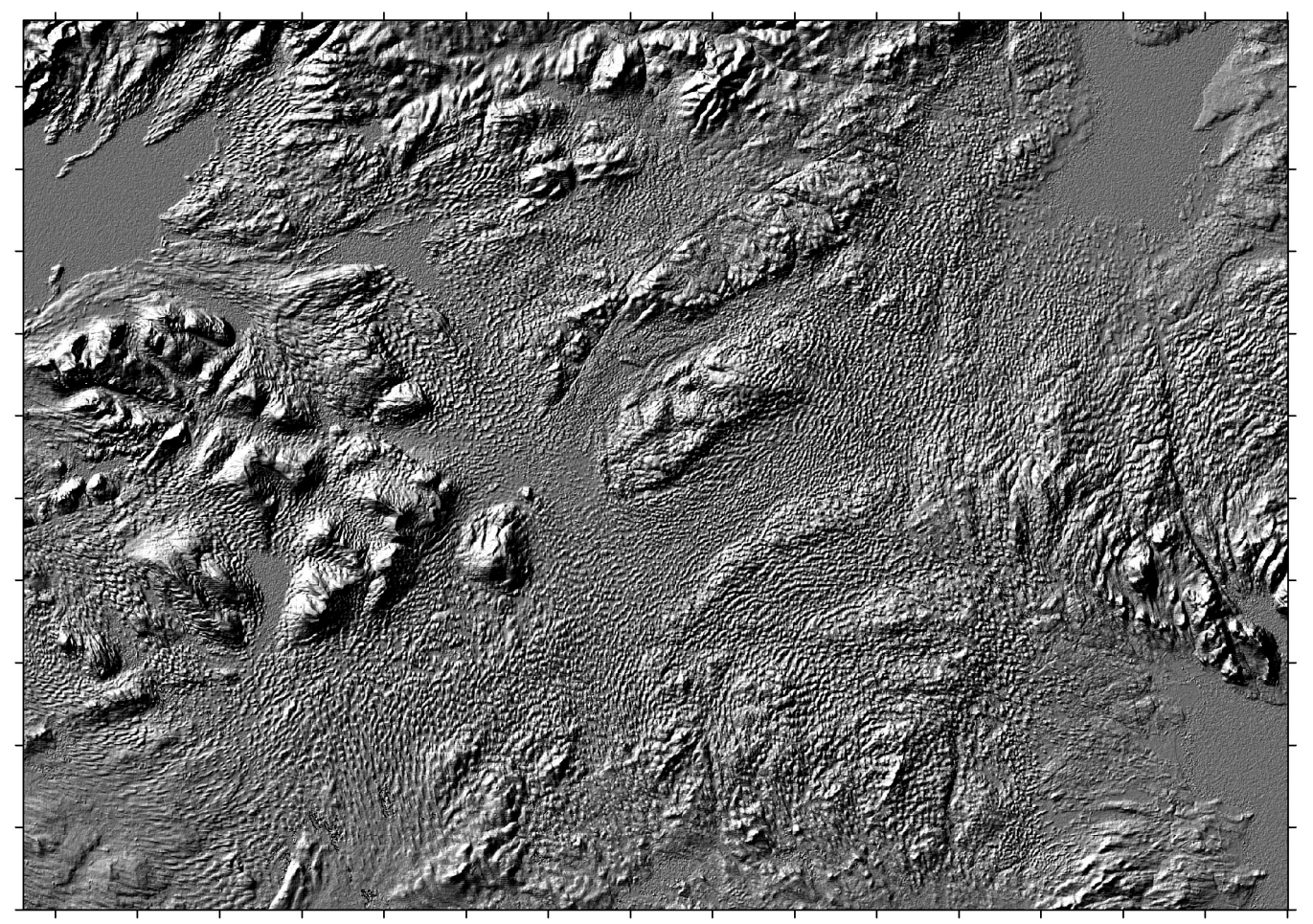

Figure 2: The field of drumlins and ribbed moraine depicted on a digital elevation model of north central Ireland. Image is around $150 \mathrm{~km}$ in width, and provided courtesy of Chris Clark; for further information see Clark (2010, figure 2).

the hillslope; but a model would still describe their average transport by a diffusive flux downslope. Equally, even if bedload transport is irrelevant in thin films, there are other processes, such as rainsplash erosion, which have the same effect, providing a sediment flux downslope. Thus a modeller would not really distinguish between these processes as represented in his or her model.

A fallacy which can be used to object to models is the mistaken belief that a model is a true representation of reality: it is not. A model is what it says on the tin: it is a model. In the example above, we model realistic patterns of rainfall with a uniform drizzle, which is spectacularly unrealistic. In fact, we expect erosion not to occur at all when rainfall is light or non-existent, but to occur sporadically in heavy storms. But how should we model this? The answer is, it depends on the time scale of the process we are interested in. For hillslope erosion over millions of years, we average the effect by a uniform drizzle with an associated average erosion rate; if we were studying the erosive effects of a single storm, we would use quite a different quantitative prescription for erosion.

This brings me to a central tenet in the philosophy of modelling: the model you build depends on the question you ask. If I am interested in turbulent flow in a pipe, then probably the question I ask is: what is the average drag law? For this we can not do much better than to use Prandtl's mixing length theory, aligned with experiment. 


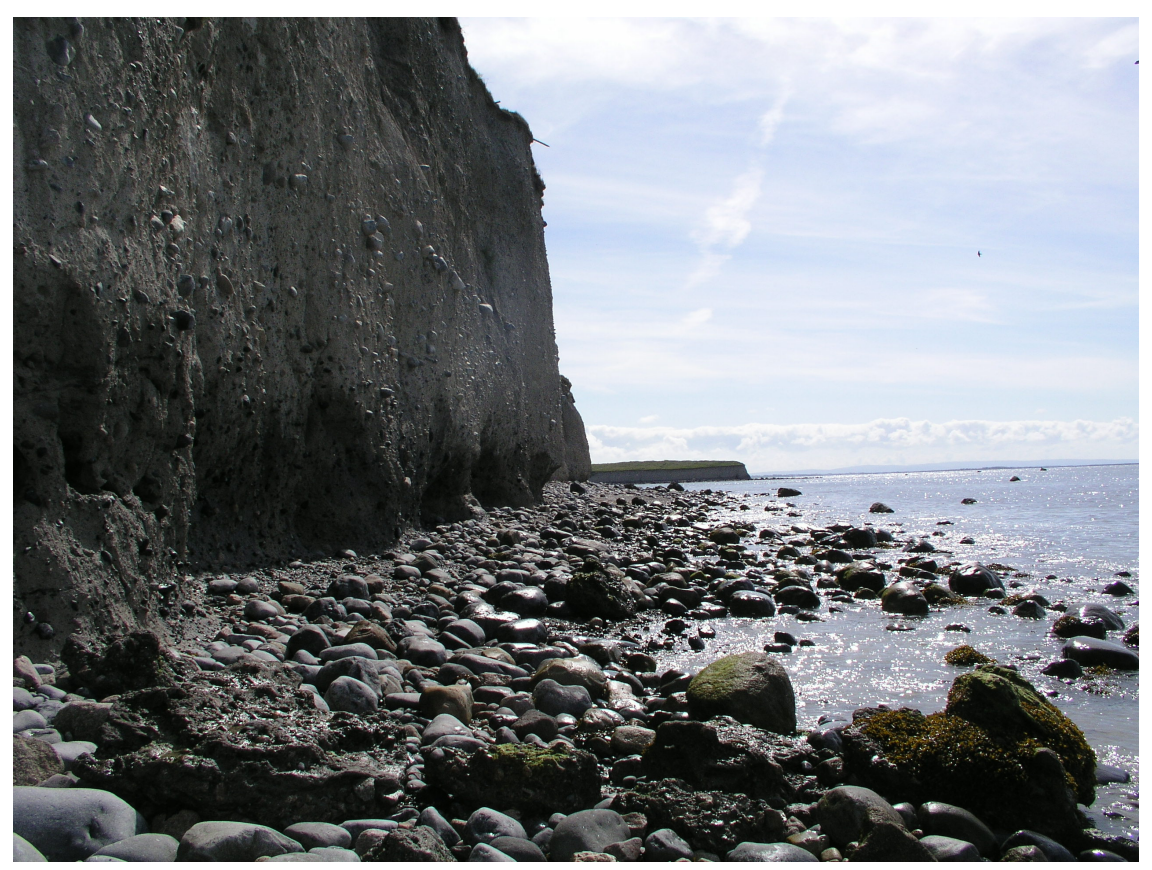

Figure 3: The Derryloney drumlin at Barna, Co. Galway.

But if I am a bacterium on the wall with a life span of a second, I will be more interested in the size and shape of the eddies, and my question will focus on the detail of their production. The question you ask depends on both the time and space scales of interest. If I am interested in the shape of the continents, then I will study continental drift and thus plate tectonics on time scales of hundreds of millions of years and space scales of thousands of kilometres; but if I am interested in the shape of volcanoes, I will study the dynamics of volcanic eruptions.

So it is with drumlins. If we are interested in explaining a large scale phenomenon such as the pattern in figure 2, then the question to ask is, how does the pattern form? Almost inevitably, the ingredients of any model must include the relief $b$ of the sediment, and some description of ice flow and sediment motion. The interior composition of an individual drumlin is not necessarily relevant to this question. On the other hand, contemplation of a cutting such as that in figure 3 raises other issues. According to McCabe (2008, pp. 75-76),

Four major, largely unconformable, facies are present in the main exposure at Derryloney. The base of the section consists of laminated and massive mud grading up into muddy diamict containing pods of pebbles and isolated cobbles. Occasional channels cutting the mud are in-filled with stratified diamict. This facies is overlain by low-angle, planar cross-stratified gravel filling channels eroded into the muddy diamict. Abrupt textural changes are common with massive and laminated sand, which contain a range of soft sediment deformation structures. The gravel is overlain by stacked beds of massive diamict separated by thin sandy stringers. All of 
the stratified facies are overlain by a carapace of massive diamict across the entire section.

This quotation is indicative of the fact that glacial geologists become fascinated and exercised by the interior construction of drumlins. And indeed, such a fascination has informed much of the drumlin literature, concerned as it has been with the question of erosional or depositional formation (e. g., Gravenor 1953, Boyce and Eyles 1991). If we are interested in explaining the interior construction as a drumlin shape evolves, we need to place our interpretation in the context of an assumed overall drumlin evolution process, but we need not know what this is, other than the fact that there is one. Particularly, this applies to depositional mechanisms, since the interior of erosional drumlins just depends on the pre-existing stratigraphy (Stokes et al. 2013). Suppose that a drumlin is formed by deposition, but consists for example of several different sand and till units ${ }^{3}$; it is then evident that, during the construction, the different layers suggest time-varying transport processes due both to ice and water. But on the large scale, these do not really matter, because the large scale pattern of the drumlinised topography invites a parameterisation of the transport processes in a similar manner to that of turbulent flow in a pipe, or of occasional storm-induced erosion. The point is that representation of sediment transport in a model by means of water-flow induced bedload, or by viscous shear-induced drag by the ice, does not mean in the model that we necessarily believe that such processes actually occur in that fashion; the point is that the terms in the equations of a model seek to represent the processes qualitatively. Equally, the issue of erosional or depositional origin, or the complexity of interior architecture, is a question of interest to stratigraphers, but it is not a question of direct concern in understanding how drumlin relief is formed. ${ }^{4}$

Those involved with the instability theory of drumlin formation have a preference for the Popperian view of scientific hypotheses, which is that the rôle of the scientist is to provide tests for failure (e.g., Dunlop et al. 2008). For applied scientists, this provides a rational basis for distinguishing between the quality of models, which otherwise, let us suppose, they do not have the means to assess. This is fair enough, but is not really what modellers actually do, and nor is it the way that (in my view) modellers should assess and discuss their own theories. We will return to a specific example of this concerning drumlins when we discuss Pelletier's (2008) theory below.

In the meantime let us mention two other examples. The first is a theory of Schoof and Clarke (2008) designed to explain the formation of subglacial flutes, whether at the metre scale of normal flutes, or the hundred metre scale of 'megaflutes', also commonly known as MSGL. Schoof and Clarke's theory is based on the concept that the rheology of ice is not that of a generalised Newtonian fluid (in which the deviatoric stresses are parallel to the components of strain rate), but can be represented by a nonlinear Reiner-Rivlin rheology, for which they quote some evidence. There are two aspects of their theory of relevance here. The first is whether the conceit of the model is actually valid. The rheology of ice is commonly described by Glen's generalised

\footnotetext{
${ }^{3}$ A possible example is Askillaun, near Louisburgh, Co. Mayo, Ireland (McCabe 2008, p. 251).

${ }^{4}$ An exception to this may be the existence of water-escape structures, which have a bearing on Pelletier's (2008) theory, discussed below.
} 
Newtonian rheology, though few would swear by its validity. However, the proposal of a radically different rheology, while interesting, is also not secure. The second aspect is that, while the resultant theory can provide an instability consistent with flute formation, the predicted widths are not well constrained (they rely on a poorly known rate of sediment slumping). In the Popperian view, it is the latter prediction which might falsify the hypothesis. Suppose, for the sake of the argument, that a predicted width of $200 \mathrm{~m}$ for a mega-scale glacial lineation was robustly predicted; the scientist might then feel that the model was a good one. However, the modeller would be less concerned with this; his focus would be on the validity of the underpinning concept, that of a nonlinear rheology. In the case of Schoof and Clarke's theory, neither theoretical premise nor consequent prediction is entirely convincing, but it provides a good example of a theory whose merits might be debated at cross purposes.

A second example is not glaciological at all, but concerns mantle convection. When the 'plate tectonic revolution' in the 1960s finally led to the acceptance of continental drift, modellers were quick to study the nature of mantle convection, which is the underlying process which causes continental drift. An early seminal paper on the subject is that of Turcotte and Oxburgh (1967), who studied thermal convection of a constant viscosity fluid in a mantle convection cell of notional depth $1,500 \mathrm{~km}$. At the time, the apparent penetration depth of subducting lithospheric plates to a depth of $700 \mathrm{~km}$ (as evidenced by the depth of deep earthquakes) together with the presence of a phase change (to perovskite) suggested that convection might be limited to the upper mantle. In addition, studies of post-glacial rebound showed that the mantle viscosity below the relatively rigid lid was relatively constant, with a value of around $10^{21} \mathrm{~Pa}$ s. Estimates of basal heating or internal radiogenic heating were less certain, but in general this problem was reasonably well constrained. The governing Rayleigh number was large, and allowed a boundary layer theory to be developed, and the resulting predictions of surface velocity were in remarkable agreement with observed plate velocities. So, it's a good theory? For its time, yes. But ultimately, no. It is certainly a remarkable and necessary paper. But the next step is a backwards one. Laboratory experiments unequivocally show that the viscosity of polycrystalline rocks depends very strongly on temperature. Where it is cold, the mantle is stiff, and indeed this is why the lithospheric plates are essentially rigid. But in fact high Rayleigh number convection in a strongly temperature-dependent viscous fluid behaves quite differently to the Earth's mantle. There is a cold, stagnant lid across which most of the temperature drop occurs. The lid is stagnant because of its high viscosity, and the surface velocity is essentially zero. And indeed, this kind of convection is the norm in planetary mantles, for example on Venus or Mars: Earth is a puzzling exception, and the explanation of its active tectonic behaviour is a good deal more complicated; see Fowler (2011) for further details. So in this case, Turcotte and Oxburgh's theory gives the right answer for the wrong reason. Remnants of this dichotomy remain in the subject today.

An implication of the necessity for tests of falsification is that a theory needs to provide predictions. This is all well and good in simple situations. For example, if I propose the Euler equations as a model for fluid flow and test the prediction of that model against the shear flow of a uniform stream past a flat plate, it will be evident 




Figure 4: Drumlin-like features at $t=370 \mathrm{y}$ in a simulation from the present state of the instability theory (Fannon et al. 2017). Ice is flowing from left to right. The colour scale gives the elevation of the bed $(b)$ in metres, while $\beta, \gamma$ and $\delta$ are dimensionless parameters in the model.

that the theory fails, while the Navier-Stokes equations will not fail. On the other hand, the Euler equations provide a perfectly good explanation for water waves. A balance needs to be struck between the demand for predictions and the capability of a model to make them in a serious fashion.

As an example, the (linear) instability theory of drumlin formation can explain rather well the observed dimensions of drumlins, and it is tempting to use that as a prediction; but really it is a null result as regards hypothesis testing, because while it can be the case that linearly unstable wavelengths are approximately the same size as the final finished product, there is no guarantee that this should be so; many nonlinear systems coarsen as they evolve, and indeed this seems to be true of the nascent ribs and drumlins found in the instability theory (Chapwanya et al. 2011). This same disconnect between the modeller and the scientist can be seen in response to theoretically produced images, such as that in figure 4 , which results from a computation of the model of the drumlin instability theory in its present state. The stock response of the scientist is 'They don't look like drumlins', to which the exasperated modeller replies 'What more do you want? They have the right size, shape, height...'. They are of course both right; the real issue is that the modeller and the scientist expect different things from the model: the modeller is ecstatic if he has even qualitative agreement with the objects he seeks to explain, while the scientist wants an exact fit to his observations. To each, a theory plays a different rôle. 


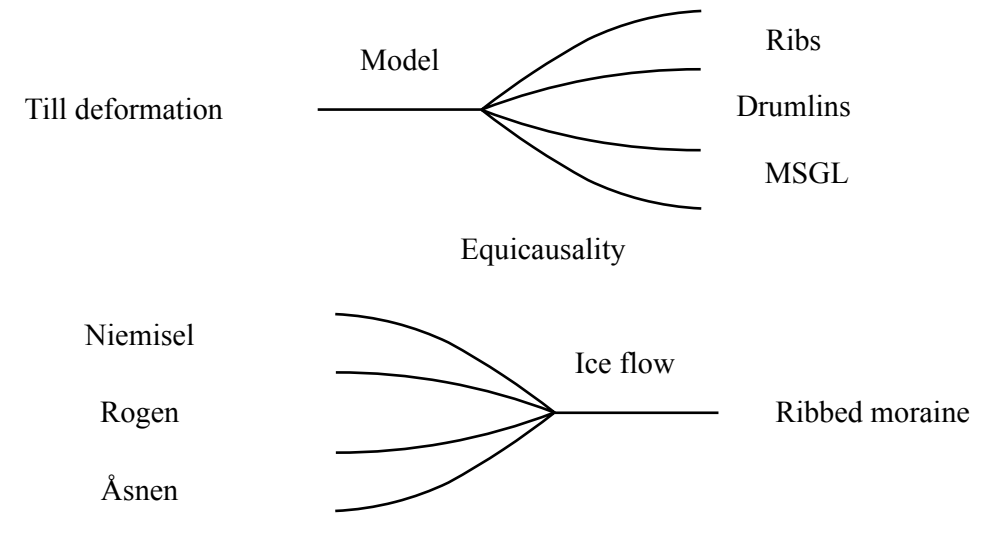

Equifinality

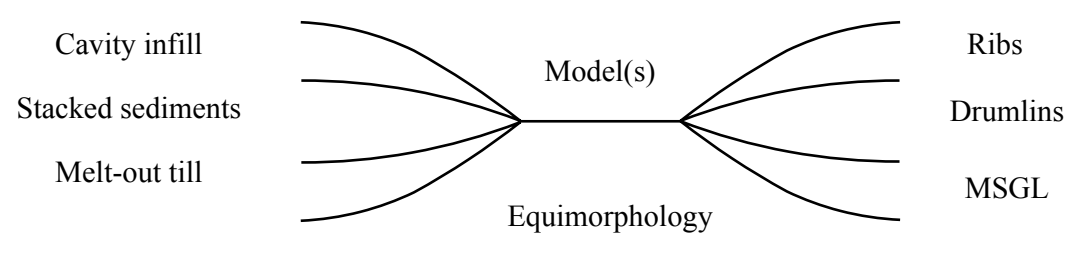

Figure 5: A schematic representation of the concepts of equicausality, equifinality and equimorphology, as explained in the text.

\section{Equifinality and equicausality}

Two different philosophical viewpoints concerning drumlin formation have been severally expressed by Clark and co-workers (e. g., Clark (2010) and Stokes et al. (2011)), who espouse the concept of equicausality, and by Möller and co-workers, who espouse the antithetical concept of equifinality (e.g., Möller and Dowling (2015), Möller and Murray (2015)).

At first sight, these two philosophies are quite different. Equicausality means that a single set of processes might be able to explain the formation of a wide variety of bedforms; specifically, the instability theory of Hindmarsh (1998) and Fowler (2000) seeks to provide a common platform for the explanation of ribbed moraine, drumlins and MSGL. On the other hand, equifinality considers a wide variety of different mechanisms to be pertinent to drumlin or rib formation, but asserts that the streamlining due to ice flow over nascent bedforms causes the resultant end products to be the same. Möller and Dowling $(2015,2016)$ ascribe this to the idea that ice flow will mould the most efficient form: Möller and Dowling (2015, p. 277) state that

... the final shape and position of these streamlined landforms is the result of a given set of initial conditions interacting with glacial processes in a semi-chaotic manner in order to create the most efficient mode of flow 
possible in the given circumstances.

Let us begin by dispelling the myth of 'ice flow efficiency'. It is not uncommon in theoretical descriptions of various phenomena to find arguments for such efficiency. Mathematically, these arguments correspond to the existence of variational principles (Howard 1972), and while such principles do sometimes exist (for example in solving Laplace's equation), this is the exception rather than the rule. Ultimately, such ideas may find their historical roots in the wispy notions of thermodynamics, where the esoteric drive to maximum entropy is allowed to provide a justification for such optimisation; but the idea is often groundless; to quote Howard (op. cit., p. 473):

One sometimes gets the impression, especially from reading general books about physics, that many people regard a variational formulation as an essential component of a true and deep understanding of the fundamental character of almost anything. This idealistic but rather narrow-minded attitude, a bit akin to the once-popular view that planetary orbits must obviously be circles, probably limits scientific progress somewhat ...;

there is no a priori reason to suppose that ice flow round an erodible corrugated landscape will engineer a bed topography which, for example, minimises drag.

Now, in consideration of figure 5, we consider first equicausality and the instability theory. In this theory we identify key processes, which are the flow of ice, the flow of water, and the deformation of till, and from these we build a mathematical model to describe these processes. In this model we identify ingredients which will enable ribbing instability (till advection) and lineation instability (fluvial sediment transport), and after that it is up to the model to see whether it can go on to produce numerical solutions which resemble reality. In its present form, this theory says nothing about internal architecture (and so, for some, is doomed from the start). As it becomes increasingly adapted towards observations, the model itself will adjust and evolve: the most notable such adjustment over the last twenty years is the explicit inclusion of subglacial water flow.

A non-modeller (let us just say a scientist) confronted with this procedure makes an error of judgement, which is to assume that the model is the process; no, it is not. For example, in the present state of the model we describe till deformation by a shearing motion, and we use a viscous formulation to describe till squeezing down effective pressure gradients. Does that mean we actually think till is viscous? No it does not, it is simply a convenient representation of the dynamic response of till to pressure gradients or shear stresses. Does it matter? There we can argue; but not on the basis of whether it is or is not viscous, but on the basis of whether it matters: that is a modeller's way of thinking. Remember, a model is just a model.

In equifinality, a bewildering array of different mechanisms of till deformation are thought to occur in different environmental settings. Per Möller, for example, describes three different mechanisms associated with three different types of ribbed moraine: Niemisel, Rogen and Åsnen, the mechanisms being roughly lee-side cavity 
infill, stacked sediments and melt-out till. ${ }^{5}$ He presumes these different mechanisms require a different model to each, and thus equicausality is ruled out. Do not be so sure! A model is not a process! In equifinality, the different processes converge because the streamlining ice flow renders them surficially indistinguishable.

My last diagram in figure 5 represents how the modeller thinks of what he does. I have called it equimorphology; equicausality means a single cause produces all the ends; equifinality means that a single end is produced by all the causes; equimorphology means that a single morphological model can represent all the causes and also produce all the ends. It may or may not produce all the ends; I think not, as flutes and perhaps whalebacks are rather different. But the issue for the scientist and the modeller to confront is whether a simple model such as I describe below can feasibly represent the differing constituent processes which occur. For me, this is the issue, and it is where the modeller and scientist must engage with each other. Getting lost in the misconceived ideas of equicausality and equifinality is not the thing to do.

There are indeed a variety of ways in which sediment can be transported: within the ice via freeze-on (Rempel 2008), by subglacial fluvial transport as bedload or as suspended sediment, or by transport within the till itself, whether by thrusting, folding or brittle fracture (Möller and Murray 2015), or simply by advection of the shearing till. The modeller, always at pains to do the simplest thing, will select the least description that he needs to get the job done. We comment more on this below. So the model is not the process, it is an impressionist's view of the process.

\section{Scientific controversies}

There are any number of scientific controversies which became bogged down in a mire of mutual incomprehension. Two that spring to mind are Wegener's theory of continental drift (Oreskes 1999), and Bretz's hypothesis of the Missoula floods (Bretz 1923, 1969). In both cases, an original controversial idea was initially rejected, but eventually accepted. Largely speaking, the observations which motivated each of these theories did not change in the meantime, and it is an interesting question for the historian of science to try and trace the evolution of scientific attitudes as they altered over the course of time. Here we will restrict ourselves to two more recent controversies of relevance to glaciology.

\section{Lliboutry versus Weertman}

In the 1960s, Lliboutry and Weertman were engaged in a debate about the basal sliding law which took on a personal tone. The battle is described by Fowler (2010). Although both were arguing theoretically, Lliboutry at one point comments to his opponent, 'it is good to have as a working tool a theory which does not conflict with numerous well-known facts' (Lliboutry 1959). We theorists would do well to bear such comments in mind.

\footnotetext{
${ }^{5}$ In his address at the meeting in his honour, "The beauty of drumlins and the mystery of their genesis", held in Lund, Sweden, May 12, 2017.
} 


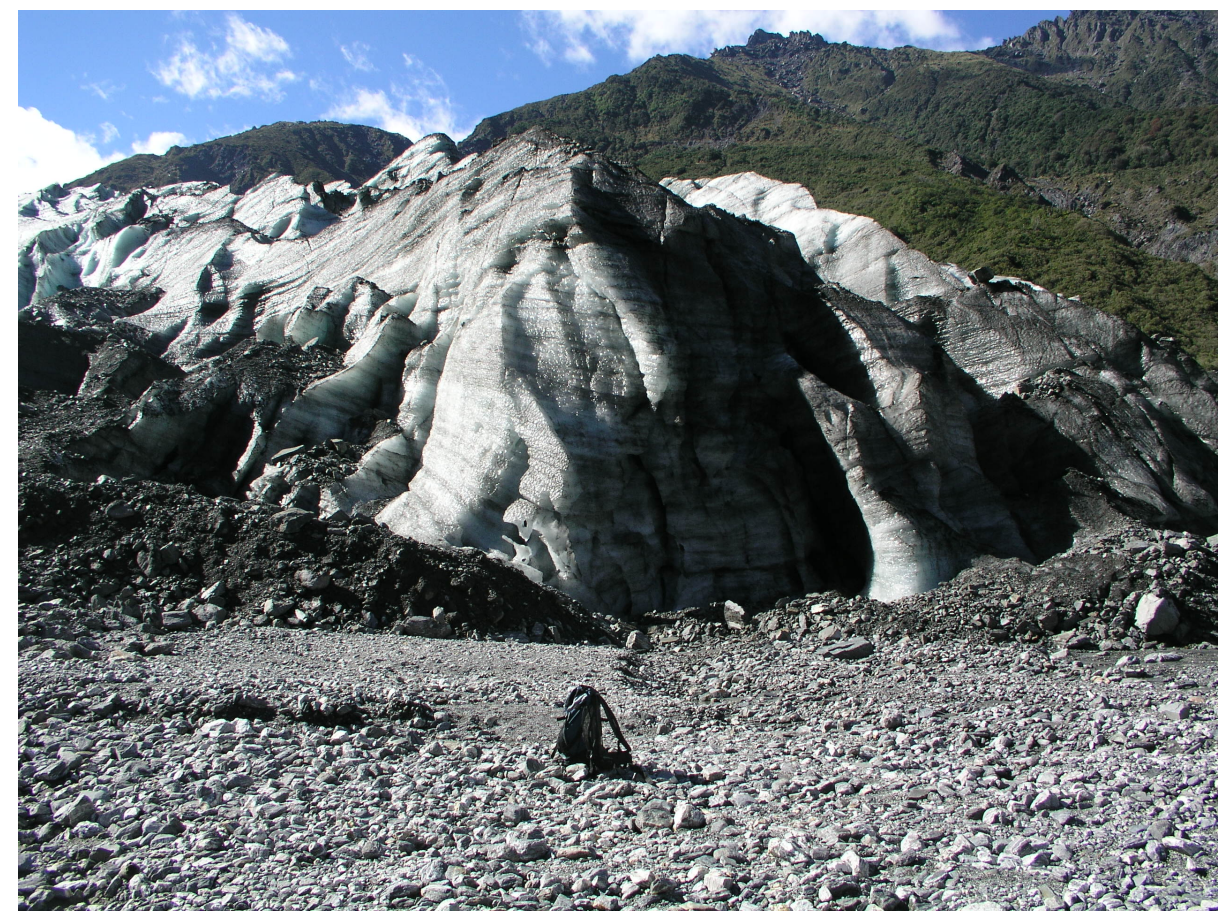

Figure 6: Forefront of the Fox Glacier, South Island, New Zealand.

Much of the debate centred on the nature of the subglacial water flow: Weertman liked the idea of a film, whereas Lliboutry promoted cavities. In the end, Lliboutry's view won through, but with a sting in the tail: despite Walder's (1982) demonstration of the instability of a Weertman film, the notion has been re-invented with the concept of a clast-filled film (Creyts and Schoof 2009).

And here is the point: despite their differences, both Lliboutry and Weertman were adherents of the 'hard bed' sliding theory, despite the evident fact that many glaciers carry a subglacial caterpillar tread of till with them, as can be inferred from figure 6 , for example, where the debris in the forefield suggests that the glacier has a similar layer at its base. As a theoretician, Lliboutry might have been minded to heed his own warning.

\section{The rheology of till}

A more recent controversy surrounds the rheology of till. As every glaciologist knows, this controversy is a consequence of Geoffrey Boulton's attempt to fit a power law rheology of the form

$$
\dot{\varepsilon}=\frac{A \tau^{a}}{N^{b}}
$$

where $a$ and $b$ are positive, to seven data points associated with the outlet glacier Breiðamerkurjökull in Iceland (Boulton and Hindmarsh 1987). Here, $\dot{\varepsilon}$ is the strain rate, $\tau$ is the basal stress and $N$ is the effective pressure (overburden minus pore water pressure). Starting with Kamb (1991), numerous experimental results have shown 
that till is essentially plastic, insofar as it possesses a yield stress, and therefore (so the story goes), it should not be modelled as viscous: note Lliboutry's warning above.

And yet, the instability theory carries on using a viscous rheology. Why? Does it matter? Well, one issue that is rarely mentioned in the debate of plastic versus viscous is that simply stating that a granular material has a yield stress, does not actually completely determine a rheology: a constitutive law is needed as well; and indeed, the determination of suitable (and well-posed) constitutive laws for granular materials is an avenue of ongoing research (Iverson and Iverson 2001, Forterre and Pouliquen 2008, Damsgaard et al. 2016, Barker et al. 2016). To give a simple example, consider a simple horizontal shear flow of Poiseuille type between two parallel plates a distance $d$ apart. Assuming no slip at the boundaries and a constant viscosity $\eta$, the fluid volume flux per unit width in the $(x)$ direction of flow is

$$
q=-\frac{d^{3}}{12 \eta} p^{\prime},
$$

where $p^{\prime}$ is the (negative) pressure gradient in the $x$ direction.

Now suppose instead that we wish to consider a perfectly plastic material with a yield stress $\tau_{c}$. If $z$ is the cross flow coordinate, the momentum equation (for slow flow) is just

$$
\frac{\partial \tau}{\partial z}=p^{\prime}
$$

where $\tau$ is the shear stress, so that, assuming symmetry across the centre line $z=\frac{1}{2} d$,

$$
\tau=-p^{\prime}\left(\frac{1}{2} d-z\right)
$$

(The integration constant is selcted so that the shear stress is zero at the mid-point of the channel.) If $\tau$ cannot be larger than $\tau_{c}$ but there is motion, then we must have

$$
\tau_{c}=-\frac{1}{2} p^{\prime} d
$$

But what is the velocity field? In the interior of the flow there can be no shear as $\tau<\tau_{c}$; so there is a plug flow; but we made the walls sufficiently rough that there is no slip there; how can that be?

Even such a simple example as this shows that determination of a flow rate dependent on a pressure gradient (more generally, a hydraulic gradient) is no simple matter; on the other hand it seems intuitive that if we subject a granular material to a sufficiently large pressure gradient it will flow. It is for this reason that viscous laws are still used, not because one believes they provide a correct description. A middle path is to choose a viscous rheology of the form

$$
\dot{\varepsilon}=A\left(\frac{\tau}{\tau_{c}}\right)^{m},
$$

where $m$ is very large (Hooke 2005, Tulaczyk 2006); in effect there is a yield stress $\tau_{c}$, but actually the rheology is viscous; other variants with a genuine yield stress are the Bingham and Herschel-Bulkley rheologies. 


\section{Drumlin formation theories}

Now let us turn to the consideration of different drumlin-forming theories. Just as I have a particular view as to what constitutes a model, so also do I have a view of what constitutes a theory. By theory, I mean not just a descriptive process, but a quantitative model of that process yielding (typically) partial differential equations. Where there is description but no model, the theory is to me stillborn, or perhaps better nascent: it might work, but who knows?

\section{Floods}

The first 'theory' I will discuss is one of many due to John Shaw, predicated on the occurrence of massive subglacial floods. He suggests (Shaw 1983) that drumlins form through the creation of inverted erosional marks at the base of the ice formed by massive subglacial floods. His argument is by analogy with other such marks observed in turbulent flows. Apart from the fact that it is not a theory (within my definition of the term) but a hypothesis, ${ }^{6}$ it has the weakness that its cause (massive floods) requires a source of subglacial water which is not easy to find. Shaw's basic problem is finding the water. Having said that, it has subsequently been found that (small) floods do occur under Antarctica (Wingham et al. 2006), and there is even evidence for massive floods beneath Antarctica (Denton and Sugden 2005); and there is Lake Vostok. However, Antarctica is one thing but the Laurentide is another: where could the water come from? A typical basal melt rate is about $3 \mathrm{~mm} \mathrm{y}^{-1}$, so over a catchment of $1,000 \mathrm{~km}^{2}$, the production is $3 \mathrm{~km}^{3} \mathrm{y}^{-1}$; to fill a decent size lake would take of the order of millennia; how could this happen?

There is a possible source, itself suggested by Shaw (1996). One explanation for Heinrich events is that the portions of the Laurentide Ice Sheet, and particularly the Hudson Strait ice stream, surged 'periodically' (MacAyeal 1993, Fowler and Schiavi 1998), with a period of 5,000-10,000 years; the surge took place along the Hudson Strait and drew down the ice over Hudson Bay, perhaps by 1,000 m. Following such a surge, there could be a depression in the ice over Hudson Bay compared to its surroundings, in addition to which the lower ice elevation would cause increased summer melting; so there is the possibility of melt water accumulating in the depression, helped by the positive feedback associated with the reduced albedo of the water body; and a sufficiently large body will break through the ice to the bed (where the adverse slope of the ice sheet may trap it).

So Shaw's idea of floods could conceivably work; but for it to become a viable theory needs a good deal of modelling work. In its present state it is no more than an idea.

\footnotetext{
${ }^{6}$ Just as the word 'model' has different connotations to different people, so also does the word 'theory'; some hold that an idea of a process is a sufficient content, whereas my view is that that constitutes a hypothesis; to me, a theory is a description of process and its elucidation by computation or other such demonstration.
} 


\section{Dewatering and till deformation}

Jon Pelletier has adumbrated a quite different theory. This dates from about 2004, but was never published as a paper, but instead appears in his book (Pelletier 2008). He has kindly sent me a draft of his unpublished paper (which is essentially the same as the account in his book), and the following comments pertain to this.

Pelletier's theory is based on an analogy he draws between saturated till and partially molten rock in the Earth's mantle (specifically, in the asthenosphere), and so a digression to describe this latter context is necessary. The polycrystalline rocks of the Earth's mantle convect under the influence of both internal (radioactive) heat generation, and also heating from the outer core below, and where upwellings occur, either at mid-ocean ridges or at hot spots such as Hawaii, the decrease in pressure causes pressure-release melting. The rock partially melts (to about $1 \%$ volume melt), and this melt forms at grain boundaries, and the resultant pores of melt form a connected network which thus allows the melt to drizzle upwards under its buoyancy.

Ultimately, the melt might freeze on to the base of the lithosphere, but sometimes it can penetrate the lithosphere and the crust by magmafracturing, and then it tends to pond in magma chambers several kilometres below the Earth's surface, where it may either freeze, or supply volcanic eruptions.

It is thought that a uniform Darcy flow through the porous asthenosphere is likely to be unstable to the formation of channels, much as overland flow is unstable to the formation of channels, and indeed the same mechanism of instability applies: in overland flow, increased film thickness drives increased erosion which drives further increase of the film thickness; in the asthenosphere, increased porosity causes increased melt velocity which causes increased pressure-release melting of the upwelling mantle rock (Fowler 2011, pp. 557 ff.), which further increases porosity; thus an arborescent 'cave' system (analogous to those in karst) may reasonably occur in the asthenosphere. ${ }^{7}$

It is this instability which lies at the heart of Pelletier's model. Models to describe the porous medium flow in the asthenosphere take the form of two-phase flow equations, in which inertial terms are neglected, and the interfacial drag term is constituted analogously to that which leads to Darcy's law. The theory was independently promoted by Scott and Stevenson (1984), McKenzie (1984) and Fowler (1985), with all three theories being essentially equivalent, but only Fowler provides a physical interpretation for the compaction term which manifests itself as a bulk viscosity in the theory.

McKenzie's theory, which is the most widely cited, proposes a bulk viscosity for the two-phase mixture, although without any justification for such a term. However, consultation of Batchelor's book (Batchelor 1967, p. 253) provides a physical explanation for this term: the compaction term is due to the pressure difference between solid and pore fluid, which drives a viscously induced contraction of the pore space, precisely analogous to the way in which borehole closure occurs (Nye 1953). At shal-

\footnotetext{
${ }^{7}$ Because temperate ice is also a partially molten crystalline 'rock', the transport of its melt through a corresponding porous vein network can be described by a similar theory; see for example Shreve (1972), Nye (1976), Fowler (2001).
} 
lower depths, in the crust, a similar term can arise through the mechanism of pressure solution (Fowler and Yang 1999). The theory has been used in other contexts such as for a crystal pile in a magma chamber (McKenzie 2011), where it is less obviously applicable.

In a similar manner, Pelletier's theory starts from the conceit that saturated subglacial till can also be represented in this fashion, that is as a viscous compacting material, and thus subject to the same basic governing equations, and he associates drumlins with an instability in which excess porewater is concentrated in drumlins (Menzies 1979), somewhat analogously to the channelling instability in the asthenosphere. In his theory, therefore, the over-riding ice plays little rôle. This is an attractive feature, because it allows to drumlins to grow without being translated, as for example occurs in the instability theory.

In my opinion, there are two weaknesses of the theory in its present form; one lies in the formulation of the model, the other in its implementation. I will mention only the first of these. The problem in the formulation lies in the assumption that till is a viscously compacting material, and can be modelled in a similar fashion to Spiegelman (1993); and here we can have a proper modelling argument. This assumption is made on the basis of constitutive similarity to partially molten rock, but does not consider the microscopic physics which underlies compaction. As discussed above, the choice of a viscous rheology for the till is defensible, but, I would argue, the compaction relation is not: the sediment grains do not deform viscously, nor is pressure solution viable. Thus the basis for the use of a compaction model is undermined.

And yet, some of my scientific colleagues were rather impressed by Pelletier's numerical computations. Scientists tend to believe what they see, and to assume that a model is like a thermometer - it works. But actually modelling is a technically hard and convoluted art, and one should not necessarily believe what one sees.

\section{The instability theory}

The idea that drumlins form by means of an instability was first suggested by Patterson and Hooke (1995), although they did not provide an actual theory; later, Hooke and Medford (2013) suggested a possible instability mechanism based on the interaction of the temperature field with the flow of ice. The instability theory, as it is commonly called, originates with the work of Hindmarsh (1998) and Fowler (2000). In its original form, it dealt with the flow of ice over deformable till, with the other basal constituent, water, playing a passive rôle. In subsequent developments, basal water has been treated with ever-increasing degrees of realism, so that in its present form (Fannon et al. 2017), water, ice and till play equal rôles.

To call it the instability theory is a bit of a misnomer, because the image in figure 2 almost demands that drumlins grow through an instability mechanism ${ }^{8}$; the issue is to determine the physical processes which cause such instability. The instability theory takes its inspiration from aeolian or fluvial dunes, which are formed by the

\footnotetext{
${ }^{8}$ Well, it depends on your background; to an applied mathematician, steeped in theories of pattern formation in biology and fluid mechanics, for example, instability is relentlessly associated with the formation of pattern.
} 
erosive action of flowing air or water over sand. In particular, it assumes that ice grips the till, causing it to undergoing shearing flow. As well as this, the model allows for till to be squeezed down an effective hydraulic gradient, and also to be carried along by a subglacial water flow as bedload. Water flow is considered to take place in a Creyts-Schoof film in which clasts are present which penetrate (and thus grip) the ice (Creyts and Schoof 2009), and is described by a local Poiseuillle flow, while the ice is taken to be Newtonian viscous (this simplification allowing the ice flow to be solved explicitly via Fourier transforms). The resulting theory is hard to compute, but such results as there are suggest that it fits most of the basic geometric observations; whether in practice it includes the correct basic processes is not so clear (see below). It has little to say about internal stratigraphy, although Stokes et al. (2013) assert that observations of drumlin interiors can be accommodated by it. Possibly the main weakness of the instability theory is that it is predicated upon multiple assumptions which are reasonable but not inevitable: the pore pressure is high so that till can deform, the sliding law is of the generalised Weertman form

$$
\tau=R u^{p} N^{q}
$$

where $p$ and $q$ are positive constants, $\tau$ is basal shear stress, $u$ is basal ice velocity, and $N$ is the effective pressure, there is a yield stress $\propto N$, and the rheology when this is reached is effectively viscous, and, importantly, sediment can be transported by the stream flow. This important assumption requires an interpretation of water flow, which in steady conditions in the interior of an ice sheet would occur in a film of millimetric thickness. The only way sediment transport can be accommodated is by supposing that the water flow is intermittent, and occurs in occasional floods, but in fact this is entirely reasonable (Wingham et al. 2006); the alternative is that drumlins only form near the margin of an ice sheet, as suggested by Patterson and Hooke (1995), where meltwater is plentiful due to supraglacial melt penetration to the bed at distances from the margin of the order of $100 \mathrm{~km}$ (Sundal et al. 2009), and subglacial streams are likely to be significant, but the instability theory in its present form does not really deal with this situation.

\section{Mulajökull}

The recent programme of research on the bedforms exposed under Mulajökull, Iceland (McCracken et al. 2016) represents a major achievement in glaciological research, comparable to the investigations on Variegated Glacier, Alaska in the 1970s and 1980s. Mulajökull is a surging glacier in Iceland, whose advances and subsequent retreats have revealed the formation of drumlins. Just as in the Variegated work, meticulous observations have led to the construction of a theoretical model designed to coincide with the observations (Iverson et al. 2017). The principal feature in which this model differs from others lies in the idea that sediment transport occurs by regelation infiltration, i. e., the sediment is frozen on to the base of the glacier and then released by enhanced melting as the ice surges forward.

Observations at Mulajökull indicate that between surges of the glacier, the effective pressure $N$ is lower on the forming drumlins than between them, and this is one 
of two statements made by McCracken et al. (2016) to suggest that the instability theory can not apply to the drumlins at Mulajökull (the other, that there is no evidence of compressive stresses in the till, appears to be a misinterpretation, as the instability theory supposes that till motion is essentially by shear). This objection is evidently valid (and reminiscent of a similar statement by Menzies (1979)), but it has to be said that the prospect of building a theory for drumlin growth which simultaneously copes with surging glacier behaviour is fairly monumental. It is difficult to say anything very sensible about how one would adapt the instability theory to this new circumstance. For a start, if we follow the classic mechanism of surges outlined by Kamb et al. (1985), we would suppose a Röthlisberger (1972) system of channels existed in between surges, with high effective pressure, and low effective pressures during the surge. This would assist the till advance during the surge which is documented, and the erosion from the inter-drumlin areas in the quiescent phase could be associated with till squeezing into the $\mathrm{R}$ channels and being transported downstream.

Iverson et al. (2017) have begun the tricky task of building a model based on their observations. This is a first attempt at a coherent theory and there is a good deal more to be done, in terms of predicting some of the measurable quantities such as drumlin size. The most interesting aspect of the theory is the use of freeze-on and thaw-out as a mechanism for till transport. It may be that this is another of those known but overlooked processes that theoreticians will have to pay more attention to in the future.

\section{A lattice model}

The last model we will discuss is a lattice-type model due to Barchyn et al. (2016), similar to models which have been used for a long time in landscape evolution studies (Tucker and Slingerland 1994). The best one can say of this is that it shows that a single model can produce the range of bedforms (ribs, drumlins, lineations) which are observed. On the other hand, the 'model' is a fairly simply contrived set of relations which appear designed to do the job. As an example, their equation (2) appears to suggest that the effective pressure is an increasing function of bed slope, for no apparent reason other than it 'works', i. e., produces the result required. Such exercises may have their uses, but from a modeller's point of view, this is essentially rather sophisticated curve-fitting.

\section{Conclusions}

In a correspondence with a highly regarded geomorphologist, we exchanged views on the rights and wrongs of our various competing theories. In the rational way in which such dialogues take place, the correspondence nevertheless became slightly heated. At a certain point, I offered the following view:

A theory is just that, something you spit out and then people savage or not, but it is not a belief system ...to me, science is about engagement, there is no hierarchy. 
And this I believe. Scientists, if they were as intelligent as one would suppose, would realise that they have made grotesque errors in the past (Aristotle, Ptolemy, Copernicus, early 19th century geology, continental drift, the Missoula floods ...), and so we should realise that those same errors are being made today. The only way to avoid falling into the trough of wrong theories is not to believe in them. And actually, the genuine mathematical modeller is, astonishingly, in a perfect place to carry this principle through; because, by the nature of what he does, he doesn't believe in his model, because he knows it is not reality; it is a model, just that and only that. Modellers, true to this creed, may not have many skills, but, if they do their job properly, they may actually serve as torchbearers in leading science forward.

\section{Acknowledgements}

I acknowledge the support of the Mathematics Applications Consortium for Science and Industry (www.macsi.ul.ie) funded by the Science Foundation Ireland mathematics grant 12/IA/1683. Many thanks to Chris Clark for his comments on an earlier draft.

\section{References}

Barchyn, T. E., T. P. F. Dowling, C. R. Stokes and C. H. Hugenholtz 2016 Subglacial bedform morphology controlled by ice speed and sediment volume. Geophys. Res. Letts. 43, doi:10.1002/2016GL069558.

Barker,T., D. G. Schaeffer, M. Shearer and J. M. N. T. Gray 2016 Well-posed continuum equations for granular flow with compressibility and $\mu(I)-$ rheology. Proc. R. Soc. Lond. A473, 20160846.

Batchelor, G. K. 1967 An introduction to fluid dynamics. C. U. P., Cambridge.

Boulton, G. S. and R. C. A. Hindmarsh 1987 Sediment deformation beneath glaciers: rheology and geological consequences. J. Geophys. Res. 92 (B9), 9059-9082.

Boyce, J. I. and N. Eyles 1991 Drumlins carved by deforming till streams below the Laurentide ice sheet. Geology 19, 787-790.

Bretz, J. H. 1923 The Channeled Scablands of the Columbia Plateau. J. Geol. 31, 617-649.

Bretz, J. H. 1969 The Lake Missoula floods and the Channeled Scabland. J. Geol. $77,505-543$.

Clark, C. D. 2010 Emergent drumlins and their clones: from till dilatancy to flow instabilities. J. Glaciol. 51, 1,011-1,025. 
Chapwanya, M., C.D. Clark and A.C. Fowler 2011 Numerical computations of a theoretical model of ribbed moraine formation. Earth Surf. Process. Landf. 36, $1,105-1,112$.

Creyts, T. T. and C. G. Schoof 2009 Drainage through subglacial water sheets. J. Geophys. Res. 114, F04008.

Damsgaard, A., D. L. Egholm, L. H. Beem, S. Tulaczyk, N. K. Larsen, J. A. Piotrowski and M.R. Siegfried 2016 Ice flow dynamics forced by water pressure variations in subglacial granular beds. Geophys. Res. Letts. 43, 12,165-12,173.

Denton, G. H. and D. E. Sugden 2005 Meltwater features that suggest Miocene icesheet overriding of the Transantarctic Mountains in Victoria Land, Antarctica. Geograf. Ann. 87A, 67-85.

Dunlop, P., C. D. Clark and R. C. A. Hindmarsh 2008 Bed Ribbing Instability Explanation: testing a numerical model of ribbed moraine formation arising from coupled flow of ice and subglacial sediment. J. Geophys. Res. 113, F03005.

Fannon, J. S., A. C. Fowler and I. R. Moyles 2017 Numerical simulations of drumlin formation. Proc. R. Soc. Lond. A, in press.

Forterre, Y. and O. Pouliquen 2008 Flows of dense granular media. Ann. Rev. Fluid Mech. 40, 1-24.

Fowler, A. C. 1985 A mathematical model of magma transport in the asthenosphere. Geophys. Astrophys. Fluid Dyn. 33, 63-96.

Fowler, A. C. 2000 An instability mechanism for drumlin formation. In: Deformation of glacial materials, eds. A. Maltman, M. J. Hambrey and B. Hubbard, Spec. Pub. Geol. Soc. 176, pp. 307-319; Geological Society, London.

Fowler, A. C. 2001 Modelling the flow of glaciers and ice sheets. In: Continuum mechanics and applications in geophysics and the environment, eds. B. Straughan, R. Greve, H. Ehrentraut, and Y. Wang, Springer-Verlag, Berlin, pp. 201-221.

Fowler, A. C. 2010 Weertman, Lliboutry and the development of sliding theory. J. Glaciol. 56 (200), 965-972.

Fowler, A. 2011 Mathematical geoscience. Springer-Verlag, London.

Fowler, A.C. and E. Schiavi 1998 A theory of ice sheet surges. J. Glaciol. 44, 104-118.

Fowler, A.C., N. Kopteva and C. Oakley 2007 The formation of river channels. SIAM J. Appl. Math. 67, 1,016-1,025.

Fowler, A. C. and M. Chapwanya 2014 An instability theory for the formation of ribbed moraine, drumlins and mega-scale glacial lineations. Proc. R. Soc. Lond. A470, 20140185. 
Fowler, A.C. and Xinshe Yang 1999 Pressure solution and viscous compaction in sedimentary basins. J. Geophys. Res. 104, 12,989-12,997.

Gravenor, C. P. 1953 The origin of drumlins. Amer. J. Sci. 251, 674-681.

Hindmarsh, R. C. A. 1998 The stability of a viscous till sheet coupled with ice flow, considered at wavelengths less than the ice thickness. J. Glaciol. 44, 285-292.

Hooke, R. LeB. 2003 Predictive modeling in geopmorphology: an oxymoron? In: Prediction in geomorphology, eds. P. Wilcock and R. Iverson. A. G. U. Geophys. Monograph 135, 51-61.

Hooke, R. LeB. 2005 Principles of glacier mechanics, 2nd ed. C. U. P., Cambridge.

Hooke, R. LeB. and A. Medford 2013 Are drumlins a result of a thermo-mechanical instability? Quat. Res. 79, 458-464.

Howard, L. N. 1972 Bounds on flow quantities. Ann. Revs. Fluid Mech. 4, 473-494.

Huppert, H. E. 2000 Geological fluid mechanics. In: Perspectives in fluid dynamics, eds. G. K. Batchelor, H. K. Moffatt and M. G. Worster, pp. 447-506. C. U.P., Cambridge.

Iverson. N. R., R. G. McCracken, L. K. Zoet, Í.Ö. Benediktsson, A. Schomacker, M. D. Johnson, J. Woodard 2017 A theoretical model of drumlin formation based on observations at Múlajökull, Iceland. J. Geophys. Res. Earth Surface 122 (12), 2,302-2,323.

Iverson, N. R. and R. M. Iverson 2001 Distributed shear of subglacial till due to Coulomb slip. J. Glaciol. 47 (158), 481-488.

Kamb, B. 1991 Rheological nonlinearity and flow instability in the deforming bed mechanism of ice stream motion. J. Geophys. Res. 96 (B10), 16,585-16,595.

Kamb, B., C.F. Raymond, W. D. Harrison, H. Engelhardt, K. A. Echelmeyer, N. Humphrey, M. M. Brugman and T. Pfeffer 1985 Glacier surge mechanism: 19821983 surge of Variegated Glacier, Alaska. Science 227, 469-479.

Kramer, S. and M. Marder 1992 Evolution of river networks. Phys. Rev. Lett. 68, 205-208.

Lliboutry, L. 1959. Une théorie du frottement du glacier sur son lit. Ann. Géophys. 15 (2), 250-265.

MacAyeal, D. R. 1993 Binge/purge oscillations of the Laurentide Ice Sheet as a cause of the North Atlantic's Heinrich events. Paleoceanography 8 (6), 775-784.

McCabe, M. 2008 Glacial geology and geomorphology: the landscapes of Ireland. Dunedin Academic Press, Edinburgh, Scotland. 
McCracken, R. G., N. R. Iverson, Í.Ö. Benediktsson, A. Schomacker, L. K. Zoet, M. D. Johnson, T.S. Hooyer and Ó. Ingólfsson 2016 Origin of the active drumlin field at Múlajökull, Iceland: new insights from till shear and consolidation patterns. Quat. Sci. Rev. 148, 243-260.

McKenzie, D. P. 1984 The generation and compaction of partially molten rock. J. Petrol. 25, 713-765.

McKenzie, D. 2011 Compaction and crystallization in magma chambers: towards a model of the Skaergaard Intrusion. J. Petrol. 52, 905-930.

Menzies, J. 1979 The mechanics of drumlin formation with particular reference to the change in pore-water content of the till. J. Glaciol. 22, 373-384.

Möller, P. 2006 Rogen moraine: an example of glacial reshaping of pre-existing landforms. Quat. Sci. Revs. 25, 362-389.

Möller, P. 2010 Melt-out till and ribbed moraine formation, a case study from south Sweden. Sed. Geol. 232, 161-180.

Möller, P. and T.P.F. Dowling 2015 The importance of thermal boundary transitions on glacial geomorphology; mapping of ribbed/hummocky moraine and streamlined terrain from LiDAR, over Småland, South Sweden. GFF 137 (4), $252-283$.

Möller, P. and T. P. F. Dowling 2016 Streamlined subglacial bedforms on the Närke plain, south-central Sweden — areal distribution, morphometrics, internal architecture and formation. Quat. Sci. Revs. 146, 182-215.

Möller, P. and A. S. Murray 2015 Drumlinised glaciofluvial and glaciolacustrine sediments on the Småland peneplain, South Sweden - new information on the growth and decay history of the Fennoscandian Ice Sheets during MIS 3. Quat. Sci. Revs. 122, 1-29.

Nye, J. F. 1953 The flow law of ice from measurements in glacier tunnels, laboratory experiments and the Jungfraufirn borehole experiment. Proc. R. Soc. Lond. A219, 477-489.

Nye, J. F. 1976 Water flow in glaciers: jökulhlaups, tunnels, and veins. J. Glaciol. 17, 181-207.

Oreskes, N. 1999 The rejection of continental drift. O. U. P., New York.

Patterson, C. and R. LeB. Hooke 1995 Physical environment of drumlin formation. J. Glaciol. 41, 30-38.

Pelletier, J.D. 2008 Quantitative modeling of Earth surface processes. C.U.P., Cambridge. 
Rempel, A.W. 2008 A theory for ice-till interactions and sediment entrainment beneath glaciers. J. Geophys. Res. 113, F01013.

Röthlisberger, H. 1972 Water pressure in intra- and subglacial channels. J. Glaciol. 11, 177-203.

Schoof C. and G. K. C. Clarke 2008 A model of spiral flows in basal ice and the formation of subglacial flutes based on a Reiner-Rivlin rheology for glacial ice. J. Geophys. Res. 13, B05204.

Scott, D. R. and D. J. Stevenson 1984 Magma solitons. Geophys. Res. Letts. 11, $1,161-1,164$.

Shaw, J. 1983 Drumlin formation related to inverted meltwater erosional marks. J. Glaciol. 29, 461-479.

Shaw, J. 1996 A meltwater model for Laurentide subglacial landscapes. In: Geomorphology sans Frontières, ed. S. B. McCann and D. C. Ford, John Wiley and Sons, Chichester, pp. 181-236.

Shreve, R. L. 1972 Movement of water in glaciers. J. Glaciol. 11, 205-214.

Smith, T.R. and F.P. Bretherton 1972 Stability and the conservation of mass in drainage basin evolution. Water Resour. Res. 8, 1,506-1,529.

Spiegelman, M. 1993 Flow in deformable porous media. Part 1 Simple analysis. J. Fluid Mech. 247, 17-38.

Stokes, C.R., M. Spagnolo and C. D. Clark 2011 The composition and internal structure of drumlins: complexity, commonality, and implications for a unifying theory of their formation. Earth-Science Reviews 107, 398-422.

Stokes, C. R., A. C. Fowler, C. D. Clark, R. C. A. Hindmarsh and M. Spagnolo 2013 The instability theory of drumlin formation and its explanation of their varied composition and internal structure. Quat. Sci. Revs. 62, 77-96.

Sundal, A. V., A. Shepherd, P. Nienow, E. Hanna, S. Palmer and P. Huybrechts 2009 Evolution of supra-glacial lakes across the Greenland Ice Sheet. Remote Sensing of Environment 113, 2,164-2,171.

Tucker, G.E. and R. L. Slingerland 1994 Erosional dynamics, flexural isostasy, and long-lived escarpments: a numerical modeling study. J. Geophys. Res. 99, $12,229-12,243$.

Tulaczyk, S. 2006 Scale independence of till rheology. J. Glaciol. 52, 377-380.

Turcotte, D. L. and E. R. Oxburgh 1967 Finite amplitude convection cells and continental drift. J. Fluid Mech. 28, 29-42. 
Walder, J.S. 1982 Stability of sheet flow of water beneath temperate glaciers and implications for glacier surging. J. Glaciol. 28, 273-293.

Wingham, D. J., M. J. Siegert, A. Shepherd and A. S. Muir 2006 Rapid discharge connects Antarctic subglacial lakes. Nature 440, 1,033-1,037. 